ROCZNIKI HUMANISTYCZNE

Tom LXVII, zeszyt $7 \quad-\quad 2019$

DOI: http://dx.doi.org/10.18290/rh.2019.67.7-2

ZOJA NOWOŻENOWA

\title{
МЕНТАЛЬНОЕ В ДИСКУРСЕ КАК ТЕОРЕТИЧЕСКАЯ ПРОБЛЕМА И НЕКОТОРЫЕ АСПЕКТЫ ЕЕ ИНТЕРПРЕТАЦИИ В РОССИЙСКОЙ ЛИНГВИСТИКЕ
}

Цель данной статьи - обсудить некоторые дискуссионные положения современной дискурсологии, связанные с интерпретацией категорий, относящихся к ментальному плану дискурса; показать, каким образом в лингвистике интерпретируется понятие «ментальное» по отношению к дискурсу. В статье предпринята попытка проанализировать то понимание, которое сложилось о данной проблеме в российском языкознании (в связи с европейской и американской традициями), обозначить векторы ее анализа и оценить дискуссии, возникшие при ее обсуждении.

Систематизация взглядов, идей, подходов, позиций, положений - в целом теоретических знаний о данной проблеме - продуктивный путь научного познания - получения нового знания. Такая систематизация позволяет установить некоторые общие и специфические особенности в теоретических трактовках, показать доминирующие методологические подходы к данному явлению, за которыми обнаруживаются объективные свойства самих исследуемых объектов.

В настоящее время в науке достаточно четко артикулируется тезис, согласно которому ментально-когнитивная программа и прагматические установки и обстоятельства формируют дискурсивные потоки, дискурсы. Внимание к ментальной стороне, как известно, является важным аспек-

Dr hab. Zoja NowożEnowa, prof. UG - Katedra Językoznawstwa i Translatoryki w Instytucie Rusycystyki i Studiów Wschodnich UG; e-mail: ifilsl@univ.gda.pl 
том в исследованиях дискурса, так как без понимания ментального трудно понять и объяснить онтологически существенные свойства дискурса. Обсуждение и понимание этой проблемы в науке осложнено рядом обстоятельств: во-первых, неоднозначностью и многомерностью самих явлений, понятий, с ними связанных, и многозначностью терминов, обозначающих ментальный план дискурса; во-вторых, многомерностью самого явления и понятия «дискурс», а также многозначностью термина «дискурс». От понимания того, что, собственно, представляет собой дискурс, зависит и то, какие ментальные образования включаются в его «состав» и какая роль им приписывается.

Дискурс один из наиболее популярных объектов исследования в лингвистической науке, в том числе и российской [см. напр. исследования В.И. Карасика, В.Е. Чернявской, В.З. Демьянкова, М.Л. Макарова, А.А. Кибрика, Н.И. Клушиной, К.Ф. Седова, О.Г. Ревзиной, Ю.С. Степанова, Е.С. Кубряковой и др.].

Понятие дискурса до сих пор так и не получило однозначного понимания. Различные понимания дискурса неоднократного обсуждались в литературе [обзор точек зрения см. напр.: Демьянков 1995; Ревзина 1999, 2005; Чернявская 2001; Тичер, Мейер, Водак, Беттер 2009; Новоженова 2010; Карасик 2002 и др.]. Однако многообразие и противоречивость существующих трактовок дискурса не помешали ученым выработать некоторые общие универсальные формулы, определяющие данное понятие. Так, в российском языкознании укоренилось определение дискурса, предложенное Н.Д. Арутюновой: «ДИСКУРС (от франц. discours - речь) - связный текст в совокупности с экстралингвистическими - прагматическими, социокультурными, психологическими и др. факторами; текст, взятый в событийном аспекте; речь, рассматриваемая как целенаправленное социальное действие, как компонент, участвующий во взаимодействии людей и механизмах их сознания (когнитивных процессах). Д. - это речь, «погруженная в жизнь» [Арутюнова 1990, 136137]. Важно отметить, что в этом определении не только подчеркивается связь текста и дискурса, но и практически отождествляются эти два понятия.

К числу признанных в дискурсологии следует отнести, как уже отмечалось, положение о значимости в его построении как когнитивно-ментальной стороны, так и коммуникативно-прагматической программы. Однако в пределах данной статьи мы не ставим себе задачу осветить все аспекты теории дискурса и все проблемные моменты интерпретации дан- 
ного явления, а ограничимся только замечаниями, необходимыми для характеристики состояния интересующей нас проблемы.

Отметим, что в российском языкознании сложилось несколько направлений понимания дискурса [см. напр.: Кибрик, Паршин 2018]. В одном из этих направлений дискурс трактуется как результат, продукт реальной языковой деятельности вместе со всеми обстоятельствами его создания и понимания [см. Кибрик 2009]. Основное внимание в нем уделяется элементарным базовым, исходным структурам построения дискурса (высказываниям, клаузам, пропозициям, предикациям и под.). Такое понимание восходит к теории 3. Харриса, который в 1952 году в своей статье Discourse analysis [Харрсис 1952] предложил называть дискурсом последовательность высказываний, сегмент текста больший, чем предложение. Такая трактовка дискурса закрепилась главным образом в англоамериканской школе [Дж. Лангакер; У. Чейф; О.Б. Йокояма и др.]. Основные положения этой школы привились и на русской почве [см. напр.: В.З. Демьянков; А.А. Кибрик; В.И. Подлесская; М.Л. Макаров; А.А. Сусов и др.]. Для исследователей «собственно лингвистического» [А.А. Кибрик] направления «исходная структура для дискурса имеет вид последовательности элементарных пропозиций, связанных отношениями конъюнкции, дизъюнкции и т.п.» [Демьянков 1979, 33]. А.А. Кибрик утверждает, что «первичной минимальной единицей дискурса, непосредственно осуществляющей референцию, является предикация (клауза)» [см. Кибрик 2009; Кибрик, Подлесская 2006].

Как видно, интерес исследователей этого направления сосредоточен на языковой стороне дискурса, «коде-языке как коммуникационном обеспечении дискурса» [Ревзина 2005, 66], на механизмах речепроизводства как отправной точке порождения дискурса, «оязыковлении акта коммуникации» [Ревзина 2005, 68], в котором этот процесс неотделим от процессов номинации (денотации). Однако напомним и подчеркнем, что механизм порождения дискурса как сложного коммуникативного явления включает и механизмы порождения высказывания, и производство текстов. Это еще одно положение современной науки, которое стало общепринятым. При этом ориентированность в исследованиях дискурса на высказывание (и их синтагматические цепочки, связность речемыслительных единиц) позиционируется как собственно лингвистическое направление исследования дискурса [см. об этом Кибрик 2003; 2013].

«Собственно лингвистическое» понимание дискурса стало противопоставляться тому пониманию, которое было сформировано под влия- 
нием французских постструктуралистов и постмодернистов [М. Фуко; Ж. Деррида; Ю. Кристева; А. Греймас]: «Дискурс в современной французской философии постмодернизма - это характеристика особой ментальности и идеологии, которые выражены в тексте, обладающем связностью и целостностью и погруженном в жизнь, в социокультурный, социальнопсихологический и др. контексты» [Философский энщиклопедический словарь, 2010]; «в этом направлении термин дискурс означает некоторый образ мышления, идеологию и то, как она проявляется словесно» [Можейко, Гутнер и др. 2018].

В целом в поисках методологической основы понимания дискурса в науке сформирована продуктивная идея о многомерности дискурса, о комплексности факторов, влияющих на процесс его формирования. Называются такие обстоятельства дискурсивного процесса, как «национально-этнические, социально-типические - жанровые, конкретно-ситуативные, речемыслительные, формально-структурные и многие другие» [Седов 2004, 8]. Необходимо подчеркнуть, что все существующие модели анализа дискурса так или иначе учитывают сложные связи языка, культуры и сознания (индивидуального или общественного). Такой многомерный подход позволил ученым проанализировать и акцентировать различные аспекты и параметры дискурса в зависимости от прагматического, когнитивного, психологического, структурно-языкового ракурсов его рассмотрения.

Важным методологическим подходом к дискурсу, сложившимся в современной лингвистике, является противопоставление в нем материального, «чисто языковой материи, основы», и идеального - ментального планов. Н.Д. Арутюнова пишет: «... другой своей стороной дискурс обращен к ментальным процессам участников коммуникации: этнографическим, психологическим и социокультурным правилам и стратегиям порождения и понимания речи в тех или других условиях» [Арутюнова 1990, 136-137].

Однако понятие «ментальный» в науке вообще и в языкознании в частности не является однозначным. Так, прилагательное ментальный, -ая, -ое, имеет два вектора семантической мотивированности. В одном случае оно связано с существительными менталитет, ментальность, которые в качестве понятий философии, культурологии, истории, социологии и под. имеют вполне определенное значение. С точки зрения философии и ряда других общественных наук (социологии, культурологии, истории и под.) ментальное, менталитет, ментальность понимается как «глубинный 
уровень коллективного и индивидуального сознания», «[...] относительно устойчивая, совокупность установок и предрасположенностей индивида или социальной группы воспринимать мир определенным образом» [Фuлософский энциклопедический словарь, 2010]. Философская энциклопедия предлагает следующее понимание этого понятия: «МЕНТАЛЬНОСТЬ (менталитет) (от лат. mens - ум, мышление, образ мыслей, душевный склад) - глубинный уровень коллективного и индивидуального сознания, включающий и бессознательное; относительно устойчивая совокупность установок и предрасположенностей индивида или социальной группы воспринимать мир определенным образом. Ментальность формируется в зависимости от традиций культуры, социальных структур и всей среды жизнедеятельности человека, и сама в свою очередь их формирует, выступая как порождающее начало, как трудноопределимый исток культурно-исторической динамики. Фиксируя устойчивую настроенность внутреннего мира человека, сплачивающую его в социальные группы и исторические общности, ментальность служит средством анализа и объяснения в гуманитарном знании, особенно в той мере, в какой его предмету присуще динамическое историческое измерение» [Новая философская энциклопедия, 2018].

Понятие «менталитет/ментальность» все активнее привлекает внимание российских исследователей - философов, историков, культурологов, языковедов, что прежде всего связано с необходимостью всестороннего осмысления социально-экономических и культурных изменений, происходивших в России в конце XX века, которые привели к глубоким изменениям идеологического, мировоззренческого характера в сознании россиян, к поискам культурной и национальной идентичности, национальнообщественной идеи в российском обществе. В российской науке складывается понимание исторической и социально-культурной обусловленности национального и индивидуального менталитетов.

Так, Н.П. Рогальская понятие «менталитет» трактует как «единство образа мыслей, культурных особенностей нации и, в частности, национального языка, детерминированное экономическими и политическими условиями жизни в историческом контексте» [Рогальская 2006]. Д.В. Полежаев отмечает, что менталитет «функционирует, преимущественно, во внесознательной социальной сфере, занимая в том числе и сферу общественного бессознательного» [Полежаев 2003, 87]. А.Я. Гуревич определяет ментальность как символы, культурные образцы, устойчивые стереотипы восприятия, нередко не осознанные полностью, потаенные от самих 
носителей, в то же время оказывающие влияние на них самих, то есть не только человек обладает ментальностью, но и она им [см. об этом Гуревич 1993].

Именно с такой трактовкой ментального связано понимание Ю.С. Степановым дискурса как особого «ментального» предназначения для языка: «Дискурс - это первоначально особое использование языка [...] для выражения особой ментальности [...] особое использование влечет активизацию некоторых черт языка и, в конечном счете, особую грамматику и особые правила лексики. И... в свою очередь, создает особый ментальный мир» [Степанов 1995, 38, 39, 44]. В.Е. Чернявская считает, что «за каждым дискурсом стоит идеологически и национально-историческая обусловленная ментальность» [Чернявская 2006, 13]. В.Е. Темнова расширяет объем ментального в дискурсе и относит к нему, кроме этнических, психологических, социокультурных стереотипов и установок участников коммуникации, также «стратегии понимания и порождения речи, определяющие при необходимости темп речи, степень ее связности, соотношение общего и конкретного, нового и уже известного, нетривиального (субъективного) и общепринятого, эксплицитного и имплицитного в содержании дискурса, выбор средств для достижения конечной цели коммуникации, фиксацию точки зрения говорящего и т.д.» [Темнова 2004, 27]. Именно такое понимание ментального, скорее всего, присутствует и в известном определении Н.Д. Арутюновой.

Другое понимание термина «ментальное» (по отношению к дискурсу) связано с его этимологическим значением в качестве заимствования из латинского через французский язык: «mental < ram. Mēns (mentis) ум, мышление; образ мыслей; душевный склад), мед., психол. Относящийся к мышлению, умственным способностям человека» [Толковый словарь иностранных слов, 1988]; «Ментальный - (лат. mens - ум, разум). Относящийся к психике, интеллекту (например, ментальный возраст)» [Толковый словарь психиатрических терминов, 1995]; «Ментальный - относящийся к психической жизни человека; умственный» [Словарь иностранных слов..., 1910]; «Ментальный - прил. связанный с разумом, с умственными способностями человека» [Толковый словарь Ефремовой, 2000].

Именно это значение входит в смысловую структуру понятия «ментальное», функционирующее в том направлении исследований дискурса, которое некоторые лингвисты называют собственно лингвистическим.

Ментальный план дискурса обсуждается здесь прежде всего в терминах «мышление», «сознание», «знание», «познание», а также в частных 
специальных терминах - ментальные модели, ментальные структуры, ментальные репрезентанты, концептуальные модели, ментальные пространства, фреймы, планы, сценарии, концепты и нект. др. Как мы видим, такое понимание касается прежде всего когнитивных структур в коммуникативном процессе. Когнитивный подход к дискурсу, как пишет А.А. Кибрик, предполагает, что «языковая деятельность представляет собой один из видов когнитивной деятельности человека, и языковые явления могут быть адекватно поняты лишь в контексте других когнитивных процессов, таких как представление, знание, память, внимание, сознание» [Кибрик 2003, 5]. В когнитивной лингвистике «в ментальную сферу когнитивное пространство человека - включается весь массив знаний об окружающем мире» [Олешков 2009, 68]. Ученые указывают на то, что дискурс представляет собой и реализацию, и одновременно источник когнитивных моделей [Макаров 1998, 98].

Для понимания проблемы взаимосоотношения дискурса и сознания основополагающее значение имела работа У. Чейфа 1976 г. [1982], в которой постулировался тезис: квант дискурса (интонационная единица) соответствует одному фокусу сознания. Идеи У. Чейфа оказались востребованными в науке и повлияли на понимание проблемы дискурса и сознания и в российском языкознании.

По мнению М.Л. Макарова, в дискурсе представлены «как минимум две когнитивные модели: одна из них относится к структуре предметно-референтной ситуации, другая конструирует «процедурную» ситуацию общения, сценарий эпизода самого коммуникативного взаимодействия» [Макаров 1998, 123]. Первая когнитивная модель отражает создание предметно-материальной основы дискурса, реализуется в пропозициях и отражает предметно-референтную ситуацию коммуникации [см. Панкрац 1992; Fodor 1983; Dijk 1995]. И.П. Сусов считает, что пропозиция является элементарной единицей сознания, имеющей либо предикатно-аргументный, либо субъектно-предикатный характер [см. об этом Сусов 1998, 7-13]. «Сейчас принято считать, - пишет исследователь, - что знание, являющееся основой сознания, устроено главным образом как совокупность и система пропозиции» [Сусов 1998, 9].

Особый акцент ученые делают на роли, приписанной языковым средствам в дискурсе: «назначение системы языковых средств заключается прежде всего в обеспечении связи структур дискурса и структур сознания: «последнее кодируется в первое посредством языкового механизма» [Макаров 1998, 124]. Акцент в этом процессе делается на акте референ- 
ции как мотиве речевой деятельности на основании когнитивной интерпретации предметной ситуации [см. об этом Чейф 1976 [1982]; Макаров 1998; Кибрик 2003]. Близки к этим размышлениям и идеи А.А. Кибрика, предполагающего, что процесс референции, выбор референциальной формы происходит под действием «большого количества одновременно действующих дискурсивынх факторов, существующих как комплекс мыслительных операций, «соединяющих» языковую основу дискурса с экстралингвистической ситуацией в момент порождения речи, т.е. за вербальной реализацией дискурса стоят когнитивные структуры» [Кибрик 2003, 7].

Итак, анализ ментального в дискурсе находится в центре внимания когнитивной лингвистики. В когнитивной лингвистике ключевым является понятие ментальной репрезентации, относящееся как к процессу представления «репрезентации мира в голове человека», так и к единице подобного представления, стоящей вместо чего-то в реальном или вымышленном мире и потому замещающей что-то в мыслительных процессах [Краткий словарь когнитивных терминов, 1996, 96-160]. Организация ментальных репрезентаций может быть описана в различных терминах, в том числе в терминах «фрейм», «скрипт», «сценарий». Все эти описания характеризуют лишь отдельные аспекты когниции с помощью ментальных репрезентаций.

Развертывание дискурса как вербального образования последовательности пропозиций происходит, как уже говорилось, на основе планов, фреймов, фреймовых моделей, сценариев. Именно они, по мнению ученых [см. напр. Сухих 1998; Макаров 1998], управляют коммуникативными действиями. Они содержат «информацию социокультурного характера, или знания о том, что Л. Витгенштейн называл «языковыми играми».

Вербальные ассоциации связаны со сценариями речевого поведения, существующими в человеческом сознании в виде фреймов. По мнению ученых [М.Л. Макаров и др.], фрейм - это организованная вокруг какоголибо концепта когнитивная структура в феноменологическом поле человека, которая основана на вероятностном знании о типических ситуациях и связанных с этим знанием ожиданиях по поводу свойств и отношений реальных или гипотетических объектов [Макаров 2003, 153].

Сценарий, в отличие от фрейма, как утверждает М.Ю. Олешков, отражает в ментальной сфере коммуникантов стандартную последовательность событий на уровне структуры ситуаций («ситуативного» знания) [Олешков 2006]. 
Когнитивные механизмы сцепления простейших предикаций могут быть представлены и как ментальные пространства, постоянно модифицируемые когнитивные конструкты, которые строятся в режиме реального времени в ходе дискурсивной деятельности и хранятся в оперативной памяти говорящего. Понятие ментальных пространств было предложено Ж. Фоконье. В его понимании, это области, используемые для порождения и объединения информации [Fauconnier 1994]. Дж. Лакофф видит в ментальном пространстве концептуализацию и конструирует это пространство через сущности как реальность в интерпретации субъекта: в вымышленных ситуациях, в прошлом или будущем, гипотетических ситуациях, в сфере абстрактных категорий [Lakoff 1987]. По мере создания дискурса между ментальными пространствами устанавливаются временные, пространственные, идентифицирующие, контрафактуальные, причинно-следственные и другие связи. Ментальные пространства, как указывают авторы предложенной теории Ж. Фоконье и М. Тернер [Turner, Fauconnier 2002], не заложены в нашем сознании в виде готовых структур, а возникают заново в ходе порождения дискурса.

Понятие ментальных структур, ментальных механизмов лежит и в основе когнитивной модели коммуникативной трансакции О. Йокоямы $[2005,58]$. Она оперирует такой ментальной структурой, как знание и предполагает, что процесс коммуникативной трансакции зависит от наличия у говорящих общих когнитивных множеств - знаний.

В соответствии со взглядами Т. ван Дейка, ментальная структура дискурса складывается из таких когнитивных феноменов, как структуры представления знаний, категорий, концептов [Dijk 1997]. Сознание оказывает влияние на процессы и продукты когниции, местом объективации которых является дискурс.

Еще одной ментальной единицей, участвующей в дискурсивном мышлении и организующей дискурс, считается концепт, понимаемый как «ментальная единица, психический ресурс нашего сознания и той информационной структуры, которая отражает знания и опыт человека» [Краткий словарь когнитивных терминов, 1996]. Концепт - это сведения о том, что индивид знает, предполагает, думает, воображает об объектах мира [см. об этом Павиленис 1983].

Дискурс, таким образом, оценивается одновременно и как процесс, и как продукт познавательной деятельности человека, т. е. когниций.

Система концептов, концептуальная база, организующая социальный и индивидуальный опыт человека, является результатом процесса позна- 
ния, которая отражается в сознании человека. Концепт, таким образом, связывает такие ментальные структуры как знание, познание, сознание и мышление. В оценке взаимоотношений дискурса и концепта в когнитивной лингвистике наметились два вектора: вектор «дискурс $\rightarrow$ концепт» и вектор «концепт $\rightarrow$ дискурс». Вектор «дискурс $\rightarrow$ концепт» раскрывает креативную роль дискурса в формировании концепта. Считается, что «содержание дискурса посредством социокультурного контекста формирует ценностную составляющую концепта» [Олешков 2009, 68].

Вектор анализа «концепт $\rightarrow$ дискурс» выявляет концепт как смысловую основу, ядро дискурса. Так, В.З. Демьянков пишет: «дискурс... концентрируется вокруг некоторого опорного концепта; создает общий контекст, описывающий действующие лица, объекты, обстоятельства, времена, поступки и т.п., определяясь не столько последовательностью предложений, сколько тем общим для создающего дискурс и его интерпретатора миром, который «строится» по ходу развертывания дискурса» [Демьянков 1982, 7].

Эти сложные ментальные процессы, фиксирующие движения информационных потоков, и их речевые и языковые репрезентации, получили название дискурсивного мышления. К.Ф. Седов пишет, что «под дискурсивным мышлением понимается особый вид вербального мышления, обслуживающего процессы порождения и смыслового восприятия дискурсов» [Седов 2004, 9]. Исследование дискурсивного мышления своим конечным объектом имеет процессы порождения, понимания и функционирования текстов.

В целом фокус анализа исследований данного направления сосредоточился именно на речевом процессе, фиксирующем функциональные связи лингвистических и экстралингвистических факторов. Ученых этого направления интересует прежде всего роль индивидуального сознания в дискурсе, то есть той части сознания, которая обеспечивает механизмы речевой деятельности, механизмы языкового структурирования и семантического осмысления отраженной в языке действительности. Дискурс в этой парадигме является вербальной манифестацией индивида и его сознания.

Однако, как уже говорилось ранее, дискурс и его ментальная сторона может быть рассмотрена и в несколько иной парадигме. Она связана с текстоцентрическим пониманием дискурса, то есть рассмотрением дискурса прежде всего в перспективе текста, а не высказывания. Акцент делается не на процессе, а на продукте дискурсивной деятельности. 
В этом направлении текст и дискурс часто отождествляются. Кроме того, происходит своего рода «укрупнение» дискурса и «укрупнение» тех обстоятельств, в котором этот дискурс осуществляется и/или под влиянием которых он формируется.

Текстоцентрическая позиция уже достаточно четко выражена в теории Т. ван Дейка, который значительно расширил семантический объем понятия «дискурс» и его трактовку. В его понимании дискурс имеет два измерения. В одном дискурс понимается как комплексное коммуникативное событие, происходящее между говорящим и слушающим, другое сводит дискурс к тексту как продукту коммуникативного действия. Дискурс, по его мнению, это речевой поток, язык в его постоянном движении, вбирающий в себя все многообразие исторической эпохи, индивидуальных и социальных особенностей как коммуникантов, так и коммуникативной ситуации, в которой происходит общение. Далее, развивая свою мысль, он указывает: «... дискурс - это сложное коммуникативное явление, включающее кроме текста, еще и экстралингвистические факторы (знания о мире, мнения, установки, цели адресата), необходимые для понимания текста» [ван Дейк 1994, 8].

Данное определение стало отправным для многих исследователей дискурса в российской лингвистике: почти все публикации по дискурсу в том или ином объеме приводят это высказывание Т. ван Дейка. В целом идеи Т. ван Дейка, М. Фуко, Ю. Хабермаса, Н. Фэркло и др., связывающие дискурс с социальными институтами в их исторической перспективе, способствовали укреплению текстоцентрической концепции дискурса в языкознании и стали базовыми методологическими положениями в российской лингвистике.

В текстоцентрической парадигме дискурс - это прежде всего текстовая структура. Текст и дискурс рассматриваются как части общего коммуникативного процесса, и в этом смысле текст является порождением дискурса. Кроме того, под дискурсом часто понимается и совокупность текстов, объединенных тематически или семантически. По мнению ряда ученых, текстоцентрический принцип является центральным в анализе дискурса [Н.Д. Арутюнова; Т. ван Дейк; Р. Водак; 3. Эгер; В.Е. Чернявская и др.].

Как уже указывалось, такое «укрупнение» понимания дискурса и исключительное внимание к тексту во многом формировалось под влиянием постструктуралистской и постмодернистской философии. Кроме того, именно постмодернистская философия выдвинула тезис о том, что 
дискурс - это вербальная форма объективации содержания сознания. Причем сознания не только индивидуального, но и общественного. При этом на характер дискурса влияют формы (экономическое, политическое, правовое, нравственное, эстетическое, религиозное, научное, философское) и уровни (научное, теоретическое и нетеоретическое - обыденное, религиозно-мифологическое, художественное) сознания [см. об этом Поппер 1983]. Сознание дает возможность выработать знания о связях, отношениях и закономерностях объективного мира, сформировать ценностное отношение к действительности, дает совокупность коллективных представлений, присущих определенной эпохе. Объективация результатов освоения мира определенным типом сознания происходит в дискурсе и через дискурс.

Особую роль в осмыслении этих процессов сыграла философская концепция М. Фуко. Лингвисты часто цитируют и обращаются в исследованиях дискурса к теории М. Фуко и предложенному им понятию «эпистема», понимаемой им как уровень культурного знания, именующий совокупность форм знаний конкретной исторической эпохи, ее неповторимый ментальный срез [Фуко 1996, 47-97]. Общепринятым стало положение о зависимости «тезауруса дискурса от исторического времени и общекультурных знаний» [Миронова 1997, 54].

Таким образом, в текстоцентрических теориях дискурса сознание трактуется как конструктивное начало дискурса. Так, П. Серио [2007] подчеркивал, что в своем исследовании он анализировал использование русского языка в советском политическом дискурсе как выражение особой ментальности (в данном случае особой идеологии). Именно это положение П. Серио замечается и подчеркивается Ю.С. Степановым [Степанов 1995]. Для представителей дискурс-анализа [Fairclough 2001] каждая социальная практика (экономическая, политическая, культурная, семейная и т. д.) связана с дискурсом (кроме других элементов) через формы сознания. В целом данная позиция ученых дает возможность исследовать связь дискурсов с определенным стилем мышления и различными формами сознания, особым менталитетом как совокупности установок и предрасположений воспринимать мир определенным образом.

Именно эти теоретические положения стали «несущими конструкциями» в методологической базе исследований дискурсов в российской лингвистике [см. напр. исследования политического дискурса: В.3. Демьянков; Е.И. Шейгал; А.Н. Баранов; А.П. Чудинов; парламентского: А.Н. Баранов; Е.Г. Казакевич; М.В. Гаврилова и др.; религиозного: В.А. Миш- 
ланов; Н.Н. Розанова; В.И. Карасик; Е.В. Бобырева; И.В. Богачевская; О.А. Прохватилова и др.; медиального: В.З. Демьянков; И.П. Лысакова; Т.В. Шмелева; В.И. Карасик; Н.И. Клушина; Л.Р. Дускаева и др.; научного дискурса: Г.Г. Хазагеров; М.П. Котюрова и др.; академического: Я.В. Зубкова и др.; анализ различных дискурсивных практик: О.С. Иссерс; см. также публикации в сборниках Саратовского университета «Проблемы речевой коммуникации» № 1-18; и под.].

Проблема соотношения дискурса и сознания получила в последнее время в российском языкознании новый поворот в связи с обсуждением таких речевых образований и их взаимоотношений, как текст и стиль, стиль и дискурс, стиль и текст [см. Новоженова 2018]. Поиски критериев их статуса заставляют исследователей анализировать и обсуждать разные стороны этих явлений, в том числе и ментальную. Так, как уже говорилось выше, в реляциях «текст - дискурс» текст признается результатом речевого процесса (дискурса), в то время как в дискурсе акцентируется его процессуальная природа [см. напр. ван Дейк 1998]. Однако в оценке взаимоотношений дискурса и сознания, текста и сознания не все прояснено и нет единства во мнениях исследователей. Так Е.С. Темнова утверждает, что речь и текст не включают понятия сознания. Этим качеством обладает только дискурс: «в отличие от текста или речи дискурс включает понятие сознание» [Темнова 2004, 168]. В то же время считается, что «в сознании в прототипической форме происходит когнитивная репрезентация типа текста» [Чернявская 2013, 68].

Функциональная стилистика, которая в связи с бурно развивающейся дискурсологией, оказалась в определенном кризисе, также ищет аргументы, позволяющие ей сохранить свое проблемное поле. Поиск таких аргументов идет и по линии стиль - сознание.

Среди параметров стиля в качестве ведущего определены формы общественного сознания (искусство, наука, политика, право, религия) [М.Н. Кожина; О.Б. Сиротинина и др.]: цели и задачи общения, кроме других факторов, «определяются назначением соответствующей формы общественного сознания, типом мышления, свойственной этой сфере» [Стилистика русского языка 2010, 90].

Как показал наш анализ, связь дискурса и сознания, как индивидуального, так и общественного, признается всеми учеными, чьи исследования были упомянуты в нашей статье. Однако в последнее время в российской лингвистике активно отстаивается точка зрения, в которой дискурсу отказывается в связи с общественным сознанием: дискурс определяется как 
«содержательно-смысловая общность текстов, а не общность формы общественного сознания» [Чернявская 2013, 117]. Эту идею в своей статье Проблема соотношения понятия стиля и дискурса в лингвистике начала ХХІ века в контексте идеи М.Н. Кожиной отстаивает О.В. Орлова [Орлова 2013]. Анализируя проблемы соотношения понятий функциональный стиль и дискурс, автор приходит к выводу, что эти две фундаментальные категории различаются тем, что они по-разному членят коммуникативное пространство. Автор на основе анализа онтологических сущностей стиля и дискурса приходит к выводу, что критерием идентификации и делимитации стилей является наличие связанности их с формами общественного сознания, а для дискурсов таким критерием является содержательно-смысловая общность текстов.

Предложенные исследователями критерии, однако, отличает ограниченность методологической базы. Первый вопрос, который возникает: остается ли дискурс в каждом случае связан с индивидуальным сознанием? И если да (трудно предположить иной ответ на этот вопрос), то в каком соотношении в этом случае находится индивидуальное и общественное сознание? Ведь та методологическая основа, к которой обращаются приверженцы данной концепции, признает не только наличие индивидуального и общественного сознания, но и их сложную связь. Кроме того, в рамках той же философской концепции отстаивается точка зрения исторической детерминированности форм общественного сознания. Так, признается, что первоначально формы общественного сознания ограничивались религией и философией. Однако новые потребности в развитии общества и человека вызывают к жизни и новые формы сознания. Развитие социальных подсистем в обществе порождает новые формы духовной жизни. Духовная сфера, являясь подсистемой общества в целом, с необходимостью реагирует на все изменения, происходящие в других его подсистемах: экономической, политической, социальной. Начиная с конца $\mathrm{XX}$ века, философия активно обсуждает вопрос о формировании новых форм общественного сознания, что обусловлено осложнением социальной системы. Так, наряду с традиционно выделяемыми религиозной, моральной, научной, эстетической, политической, называются и такие формы сознания, как экономическая, экологическая, медицинская, педагогическая, историческая и др. [см., напр. М.А. Барг 1987; В.П. Фофанов 1979]. Связываются ли эти формы с определенными речевыми формациями? Ответ на этот вопрос может быть только положительным. Являются ли эти формации стилями? Вероятно, не являются. В то же время критерий связи стилей с соответст- 
вующими формами сознания необходимо считать объективным. Аргументы, приводимые исследователями в пользу связи сознания только со стилями, не выглядят достаточно убедительными.

Таким образом, предложенный нами в статье анализ (хотя он не является исчерпывающим и окончательным) показал, что учет ментальных образований в анализе дискурса является во всех направлениях его исследования базовым методологическим положением. В целом в понимании ментального в дискурсе наметились два подхода: если когнитивная теория («собственно лингвистическая») фокусируется на индивидуальном плане ментального в дискурсе либо на «движении» ментальных пространств между говорящим и слушающим в актуальном коммуникативном процессе, то в текстоцентрическом понимании дискурса, как правило, «укрупняется» и ментальный план, акцентируется социально-культурная и историческая детерминированность ментальных составляющих дискурсивного процесса, таких как сознание, стереотипы мышления, особенности менталитета и т.д. Между данными подходами, вероятно, не должно быть антагонизма. Они обращены к разным сторонам одного явления на разных этапах его «материализации». В целом надо признать, что проблема ментальной стороны дискурса - его базовой онтологической сущности - находится в центре внимания ученых и относится к числу нерешенных.

\section{БИБЛИОГРАФИЯ}

Арутюнова, Н.Д. „Дискурс”. Лингвистический энциклопедический словарь. Ред. В.Н. Ярцев, Москва: Сов. Энциклопедия 1990 [Arutyunova, N.D. „Diskurs“. Lingvisticheskiy entsiklopedicheskiy slovar'. Red. V.N. Yartsev. Moskva: Sov. Entsiklopediya, 1990].

Барг, М.А. Эпохи и идеи: становление историзма. Москва: Мысль Язык: Русский Язык, 1987 [Barg, M.A. Epokhi i idei: stanovleniye istorizma, Moskva: Mysl' Yazyk: Russkiy Yazyk, 1987].

Ван Дейк, Т.А. „Критический анализ дискурса”. Перевод и лингвиста текста. Перевод. Текст. Языкознание. Москва: Совместное издание КЦП и Кафедры русского языка Махстрийского института переводчиков, 1994. 169-217 [Van Deyk, T.A. „Kriticheskiy analiz diskursa". Perevod i lingvista teksta. Perevod. Tekst. YAzykoznaniye. Moskva: Sovmestnoye izdaniye KTSP i Kafedry russkogo yazyka Makhstriyskogo instituta perevodchikov, 1994. 169-217].

Ван Дейк, Т.А. К определению дискурса. 1998 [Van Deyk, Т.А. K opredeleniyu diskursa, 1998]. www.nsu.ru/psych/internet/bits/vandijk2.htm [dostup: 16.08.2015].

Гуревич, А.Я. „От истории ментальности к историческому синтезу”. Споры о главном: Дискуссия по настоящему и будущему исторической науки вокруг французской школы 
«Анналов». Москва 1993 [Gurevich, А.Yа. „Ot istorii mental'nostey k istoricheskomu sintezu". Spory o glavnom: Diskussii o nastoyashchem i budushchem istoricheskoy nauki vokrug frantsuzskoy shkoly «Annalov». Moskva, 1993].

Демьянков, В.3. „Англо-русские термины по прикладной лингвистике и автоматической обработке текста". Порождающая грамматика. 1. Ред. Ю.В. Ванников. ВТСП 1979 [Dem'yankov, V.Z. „Anglo-russkiye terminy po prikladnoy lingvistike i avtomaticheskoy pererabotke teksta". 1. Porozhdayushchaya grammatika. Red. Yu.V. Vannikov. VTSP, 1979].

Демьянков, В.3. „Англо-русские термины по прикладной лингвистике и автоматической обработке текста”. Методы анализа текста. 2. Москва: Всесоюзный центр переводов ГКНТ и АН ССCР, 1982 [Dem'yankov, V.Z. „Anglo-russkiye terminy po prikladnoĭ lingvistike i avtomaticheskoř obrabotke teksta”. Metody analiza teksta. 2. Moskva: Vsesoyuznyy tsentr perevodov GKNT i AN SSSR, 1982].

Демьянков, В.3. „Доминирующие лингвистические теории конца XX века”. Язык и наука конца XX века. Москва, 1995 [Dem’yankov, V.Z. „Dominiruyushchiye lingvisticheskiye teorii kontsa XX veka”. Yazyk i nauka kontsa XX veka. Moskva, 1995].

Йокояма, О.Б. Когнитивная модель дискурса и русский порядок слов. Языки славянской культуры. Москва, 2005 [Yokoyama, О.В. Kognitivnaya model' diskursa i russkiy poryadok slov. Yazyki slavyanskoy kul'tury. Moskva, 2005].

Карасик, В.И. Языковой круг: личность, концепты, дискурс. Волгоград: Перемена, 2002 [Karasik, V.I. Yazykovoy krug: lichnost', kontsepty, diskurs, Volgograd: Peremena, 2002].

Кибрик, А.А. Анализ дискурса в когнитивной перспективе. Диссертация в виде научного доклада, составленная на основе опубликованных работ, представленная в зачетной школе ученых степеней доктора филологических наук. Москва, 2003. [Kibrik, A.A. Analiz diskursa v kognitivnoy perspektive. Dissertatsiya v vide nauchnogo doklada, sostavlennaya na osnove opublikovannykh rabot, predstavlennaya k zashchite na soiskaniye uchenoy stepeni doktora filologicheskikh nauk. Moskva, 2003].

Кибрик, А.А., Подлесская В.И. Проблема сегментации устного дискурса и когнитивная система говорящего. Москва: Ин-т русского языка РАН, 2006 [Kibrik, А.A., Podlesskaya V.I. Problema segmentatsii ustnogo diskursa i kognitivnaya sistema govoryashchego. Moskva: In-t russkogo yazyka RAN. 2006].

Кибрик, А.А. „Модус, жанр и другие параметры классификации дискурсов”. Вопросы языкознания. 2 (2009): 3-21 [Kibrik, A.A. „Modus, zhanr i drugiye parametry klassifikatsii diskursov". Voprosy yazykoznaniya. 2 (2009): 3-21].

Кибрик, А.А. 7 фактов об одном из центральных понятий современной лингвистической теории [Kibrik, A.A. 7 faktov ob odnom iz tsentral'nykh ponyatiy sovremennoy lingvisticheskoy teorii. 2013]. http://postnauka.ru/author/kibrik [dostup: 12.09.2018].

Краткий словарь когнитивных терминов. Сост. Е.С. Кубрякова, В.З. Демянков, Ю.Г. Панкрац, Л.Г. Лузина. Москва, 1996 [Kratkiy slovar' kognitivnykh terminov. Sost. Ye.S. Kubryakova, V.Z. Dem'yankov, Yu.G. Pankrats, L.G. Luzina. Moskva, 1996].

Кубрякова, Е.С., В3. Демьянков. „К проблеме ментальных репрезентаций”. Вопросы когнитивной лингвистики. 4 (2007): 816 [Kubryakova, Y.S., V.Z. Dem'yankov. „K probleme mental'nykh reprezentatsiy". Voprosy kognitivnoy lingvistiki 4 (2007): 8-16]. 
Макаров, М.Л. Интерпретивный анализ дискурса в малой группе. Тверь: Тверь. гос. ун-т., 1998 [Makarov, M.L., Interpretivnyy analiz diskursa v maloy gruppe, Tver': Tver. gos. un-t., 1998].

Макаров, М.Л. Языковое общение в малой группе: Опыт интерпретативного анализа дискурса. Дисс. ... доктора филол. наук. Тверь, 1998 [Makarov, M.L. Yazykovoye obshcheniye $\mathrm{v}$ maloy gruppe: Opyt interpretativnogo analiza diskursa. Diss. ... doktora filol. nauk. Tver', 1998].

Макаров, М.Л. Основы теории дискурса. Москва: ИТДГК „Гнозис”, 2003 [Makarov, M.L. Osnovy teorii diskursa. Moskva: ITDGK „Gnozis”, 2003].

Миронова, Н.Н. „Оценочный дискурс: проблемы семантического анализа“. Известия РАН. Серия литературы и языка 56 (1997). 4 [Mironova, N.N. „Otsenochnyy diskurs: problemy semanticheskogo analiza“. Izvestiya RAN. Seriya literatury i yazyka 56 (1997). 4].

Можейко, М.А., Гутнер Г.В., Огурцов А.П., Керимов Т.С., Дискурс. Гуманитарная энциклопедия. Центр гуманитарных технологий [Mozheyko, M.A., Gutner G.V., Ogurtsov A.P., Kerimov T.S., Diskurs. Gumanitarnaya entsiklopediya. Tsentr gumanitarnykh tekhnologiy]. https://gtmarket.ru/concepts/6987 [dostup: 25.08.2018].

Новая философская энциклопедия. Институт Философии Российской Академии Наук [Novaya filosofskaya entsiklopediya. Institut Filosofii Rossiyskoy Akademii Nauk]. https://iphlib. ru/greenstone3/library/collection/newphilenc/document/HASH523b1a8f5f21 f8487bc 452 [dostup: 12.09.2018].

Новоженова, 3.Л. „Активные процессы в стилистической системе русского языка: стиль вс. дискурс". Вестник Балтийского федерального университета им. И. Канта. Серия: Филология, педагогика, психология 2 (2028) [Novozhenova, Z.L. „Aktivnyye protsessy v stilisticheskoy sisteme russkogo yazyka: stil' vs. diskurs". Vestnik baltiyskogo federal'nogo universiteta im. I. Kanta. Seriya: Filologiya, pedagogika, psikhologiya 2 (2018)].

Новоженова, З.Л. „Дискурс: исследовательская мифологема или языковая реальность?”. Балтийский регион: миф в языке и культуре: материалы международной научной конференции, 8 октября 2010 г. Гданьск, 2010 [Novozhenova, Z.L. Diskurs: issledovatel'skaya mifologema ili yazykovaya real'nost'?". Baltiyskiy region: mif v yazyke i kul'ture: materialy mezhdunarodnoy nauchnoy konferentsii, 8 oktyabrya 2010 g. Gdan'sk, 2010].

Олешков, М.Ю. Основы функциональной лингвистики: дискурсивный аспект. Нижний Тагил, 2006 [Oleshkov, M.Yu. Osnovy funktsional'noy lingvistiki: diskursivnyy aspekt. Nizhniy Tagil 2006].

Олешков М.Ю., „Лингвиконцептуальный анализ дискурса (теоретический аспект)”, Дискурс. Концепт. Жанр. Коллективная монография. Нижний Тагил, 2009 [Oleshkov M.Yu. „Lingvikontseptual'nyy analiz diskursa (teoreticheskiy aspekt)”. Diskurs. Kontsept. Zhanr. Kollektivnaya monografiya. Nizhniy Tagil, 2009].

Онлайн Энциклопедия "Кругосвет”. Дискурс [Onlaĭn Entsiklopediya "Krugosvet". Diskurs]. A.A. Kibrik, P.B.Parshin, http://www.krugosvet.ru/enc/gumanitarnye_nauki/lingvistika/DISK URS.html [dostup: 12.09.2018].

Орлова, О.В. „Проблема соотношения понятия стиля и дискурса в лингвистике начала XXI века в контексте идеи М.Н. Кожиной”. Вестник Томского государственного университета. Филология 4 (2013) [Orlova, O.V. „Problema sootnosheniya ponyatiya stilya 
i diskursa v lingvistike nachala XXI veka v kontekste idei M.N. Kozhinoy“. Vestnik Tomskogo gosudarstvennogo universiteta. Filologiya 4 (2013)].

Павиленис, Р.И. Проблема смысла: современной логикой-философский анализ языка. Москва: Наука, 1983 [Pavilenis, R.I. Problema smysla: sovremennyy logiko-filosofskiy analiz yazyka. Moskva: Nauka, 1983].

Панкрац, Ю.Г. Пропозициональные структуры и их роль в формировании языковых единиц разных уровней, Минск-Москва: МГПИИЯ, 1992 [Pankrats, Yu.G. Propozitsional'nyye struktury i ikh rol' $\mathrm{v}$ formirovanii yazykovykh yedinits raznykh urovney, MinskMoskva: MGPIIYA, 1992]

Полежаев Д.В. Идея менталитета в русской философии «золотого века». Волгоград: Издво Волгу, 2003 [Polezhayev D.V. Ideya mentaliteta v russkoy filosofii «zolotogo veka». Volgograd: Izd-vo Volgu, 2003].

Поппер, К. Логика и рост научного знания: избранные работы. Перевод с англ. Москва: Прогресс, 1983 [Popper, K. Logika i rost nauchnogo znaniya: izbrannyye raboty. Perevod s angl. Moskva: Progress, 1983].

Ревзина, О.Г. „Язык и дискурс”. Вестник Московского ун-та. сер. 9.1 (1999) [Revzina, O.G. „Yazyk i diskurs”. Vestnik Moskovskogo un-ta. ser. 9. 1 (1999)].

Ревзина, О.Г. „Дискурс и дискурсивные формации”. Критика и семиотика. Вып. 8. Новосибирск, 2005 [Revzina, O.G. „Diskurs i diskursivnyye formatsii”. Kritika i semiotika. Vyp. 8. Novosibirsk, 2005].

Рогальская, Н.П. „Понятие «менталитет»: особенности определения”. София: рукописный журн. Общества ревнителей рус. философии 9 (2006) [Rogal'skaya, N.P. „Ponyatiye «mentalitet»: osobennosti opredeleniya”. Sofiya: rukopisnyy zhurn. Obshchestva revniteley rus. filosofii 9 (2006)]. http://virlib.eunnet.net/sofia/09-2006/text/0922.html [dostup: 05.02.2008].

Седов, К.Ф. Дискурс и личность: эволюция коммуникативной компетенции. Москва: Лабиринт, 2004 [Sedov, K.F. Diskurs i lichnost': evolyutsiya kommunikativnoy kompetentsii. Moskva: Labirint, 2004].

Серио, П. Русский язык и анализ советского политического дискурса: анализ номинации. Квадратура смысла: французская школа анализа дискурса (2007). Москва: ОАОИГ Прогресс, 2004 [Serio, P. „Russkiy yazyk i analiz sovet·skogo politicheskogo diskursa: analiz nominatsiy”. Kvadratura smysla: frantsuzskaya shkola analiza diskursa (2007). Moskva: OAOIG Progress, 2004].

Словарь иностранных слов, вошедших в состав русского языка. А.Н. Чудинов 1910 [Slovar' inostrannykh slov, voshedshikh v sostav russkogo yazyka. A.N. Chudinov 1910]. https://dic.academic.ru/dic.nsf/dic_fwords/42348/МЕНТАЛЬНЫЙ [dostup: 15.08.2018].

Современные подходы к изучению дискурса, Язык. Сознание. Язык. Коммуникация. Сб. ст. Ред. В.В. Красных, А.И. Изотов. Вып. 26. Москва, 2004 [Sovremennyye podkhody k izucheniyu diskursa, Yazyk. Soznaniye. Kommunikatsiya. Sb. st. Red. V.V. Krasnykh, A.I. Izotov. Vyp. 26. Moskva, 2004].

Степанов, Ю.С. „Альтернативный мир, Дискурс, Факт и принцип Причинности”. Язык и наука конца ХХ века, сб. статей. Москва: РГГУ, 1995 [Stepanov, Yu.S. „Al’ternativnyy mir, Diskurs, Fakt i printsip Prichinnosti”. Yazyk i nauka kontsa XX veka, sb. statey, Moskva: RGGU, 1995]. 
Сусов, И.П. „Деятельность, сознание, дискурс и языковая система”. Языковое общение: процессы и единицы : межвузовский сборник научных трудов. Калинин: Калинин. гос. ун-т. 1998 [Susov, I.P. „Deyatel'nost', soznaniye, diskurs i yazykovaya sistema”. Yazykovoye obshcheniye: protsessy i yedinitsy: mezhvuzovskiy sbornik nauchnykh trudov. Kalinin: Kalinin. gos. un-t., 1998].

Сухих, С.А. Прагмалингвистическое моделирование коммуникативного процесса. Автореферат дис. ... д-ра филол. наук. Краснодар, 1998 [Sukhikh, S.A. Pragmalingvisticheskoye modelirovaniye kommunikativnogo protsessa. Avtoreferat dis. ... d-ra filol. nauk. Krasnodar, 1998].

Темнова, Е.В. „Современные подходы к изучению дискурса”. Язык, сознание, коммуникация. Сб. статей. Ред. В.В. Красных, А.И. Изотов. Вып. 26. Москва: МАКС Пресс, 2004 [Temnova, Ye.V. „Sovremennyye podkhody k izucheniyu diskursa”. Yazyk, soznaniye, kommunikatsiya. Sb. statey. Red. V.V. Krasnykh, A.I. Izotov. Vyp. 26. Moskva: MAKS Press, 2004].

Тичер, С., М. Мейер, Р. Водак, Е. Беттер. Методы анализа текста и дискурса. Пер. с англ. Харьков: Гуманитарный центр, 2009 [Ticher, S., M. Meyyer Vodak, R., Ye. Better. Metody analiza teksta i diskursa. Per. s angl. Khar'kov: Gumanitarnyy tsentr, 2009].

Толковый словарь иностранных слов Л.П. Крысина. Москва: Русский язык, 1998 [Tolkovyy slovar' inostrannykh slov L.P. Krysina, Moskva: Russkiy yazyk, 1998]. https://dic. academic.ru/dic.nsf/dic_fwords/42348/МЕНТАЛЬНЫЙ [dostup: 12.09.2018].

Толковый словарь психиатрических терминов. Ред. В.М. Блейхер, И.В. Крук. 1995 [Tolkovyı̌ slovar' psikhiatricheskikh terminov. Red. V.M. Blě̌kher, I.V. Kruk. 1995]. https://psychiatry.academic.ru/1577/Ментальный [dostup: 12.09.2018].

Толковый словарь Ефремовой, Т.Ф.Ефремова. 2000 [Tolkovyy slovar' Yefremovoy, T.F.Yefremova. 2000]. https://dic.academic.ru/dic.nsf/efremova/276549/ментальный [dostup: 12.09.2018].

Фофанов, В.П. Экономические отношения и экономическое сознание. Новосибирск, 1979 [Fofanov, V.P. Ekonomicheskiye otnosheniya i ekonomicheskoye soznaniye Novosibirsk, 1979].

Философский энциклопедический словарь. 'Дискурс' [Filosofskiy entsiklopedicheskiy slovar'. 'Diskurs']. http://dic.academic.ru [dostup: 12.09.2018].

Фуко, М. „Порядок дискурса”. Воля к истине: по ту сторону власти, знания и сексуальности. Работы разных лет. Пер. с франц., комм. и послесл. С. Табачниковой, М. Касталь, 1996. 47-97 [Fuko, M. „Poryadok diskursa”. Volya k istine: po tu storonu vlasti, znaniya i seksual'nosti. Raboty raznykh let, per. s frants., komm. i poslesl. S. Tabachnikovoy, M. Kastal', 1996. 47-97].

Чейф, У. Данное, контрастность, определенность, подлежащее, топики и точка зрения. Х. 1. Москва: «Новое в зарубежной лингвистике», 1982 [Cheyf, U. Dannoye, kontrastnost', opredelennost', podlezhashcheye, topiki i tochka zreniya. Kh. 1. Moskva: Novoye v zarubezhnoy lingvistike, 1982].

Чернявская, Е.В. „Дискурс как объект лингвистических исследований”. Текст и дискурс. Санкт-Петербург, 2001 [Chernyavskaya, Ye.V. „Diskurs kak ob’yekt lingvisticheskikh issledovaniy”. Tekst i diskurs. Sankt-Peterburg, 2001].

Чернявская, Е.В. Дискурс власти и власть дискурса: проблемы речевого воздействия. Учеб. пособие. Москва: Флинта: Наука, 2006 [Chernyavskaya, Ye.V. Diskurs vlasti 
i vlast' diskursa: problemy rechevogo vozdeystviya. Ucheb. posobiye. Moskva: Flinta: Nauka, 2006].

Чернявская, Е.В. Лингвистика текста. Лингвистика дискурса. Москва, 2013 [Chernyavskaya, Ye.V. Lingvistika teksta. Lingvistika diskursa. Moskva, 2013].

Энциклопедия языкознания [Entsiklopediya yazykoznaniya]. http://jazykoznanie.ru/178/ [dostup: 12.09.2018].

Chafe, W. Givenness, contrastiveness, definiteness, subjects, topics, and point of view. New York: Academic Press, 1976.

Fairclough, N. The Dialectics of Discourse, 2001. http://www.ling.lancs.ac.uk/staff/norman /2001a.doc [dostup: 12.09.2018].

Fauconnier, G. Mental Spaces: Aspects of Meaning Construction in Natural Language. Cambridge University Press, 1994.

Fodor, J. Modularity of Mind. Cambrige, 1983.

Harris, Z.S. "Discourse Analysis: A sample text”. Language 28 (1952). 1: 1-30.

Lakoff, G. Women, Fire, and Dangerous Things: What Categories Reveal About the Mind. University of Chicago Press, 1987.

Turner, M., G. Fauconnier. The Way We Think. Conceptual Blending and the Mind's Hidden Complexities. New York: Basic Books, 2002.

Van Dijk, T. Cognitive discourse analysis. An introduction. University of AmsterdamUniversitat Pompeu Fabra, 1997.

Van Dijk, T. "On macrostructures, mental models, and other inventions: A brief personal history of the van Dijk-Kintsch theory”. Eds. C.A. Weaver, S. Mannes, C.R. Fletcher. Discourse comprehension: Essays in honor of Walter Kintsch. London-New York: Routledge, 1995.

\author{
MENTALNE ASPEKTY DYSKURSU \\ JAKO PROBLEM TEORETYCZNY \\ I NIEKTÓRE ASPEKTY JEGO INTERPRETACJI \\ W ROSYJSKIEJ LINGWISTYCE
}

\title{
Streszczenie
}

W artykule omówiono mentalne aspekty dyskursu. Ich zrozumienie zależy od interpretacji terminu dyskurs. W badaniach aspektów dyskursu możemy wyróżnić model kognitywny i tekstocentryczny. Należy zauważyć, że kluczowym w dyskusji jest pojęcie świadomości.

Słowa kluczowe: aspekty mentalne; dyskurs; model kognitywny dyskursu; model tekstocentryczny dyskursu. 


\title{
MENTAL ASPECTS OF DISCOURSE \\ AS A THEORETICAL PROBLEM \\ AND SOME ASPECTS OF ITS INTERPRETATION \\ IN RUSSIAN LINGUISTICS
}

\begin{abstract}
S u m m ary
The paper deals with mental aspects of discourse. Their understanding depends on the interpretation of the term discourse. In investigating mental aspects of discourse, we may employ the cognitive and text-centred models of discourse. It should be noted that the concept of consciousness in crucial in this discussion.
\end{abstract}

Key words: mental aspects; discourse; cognitive model of discourse; text-centred model of discourse. 